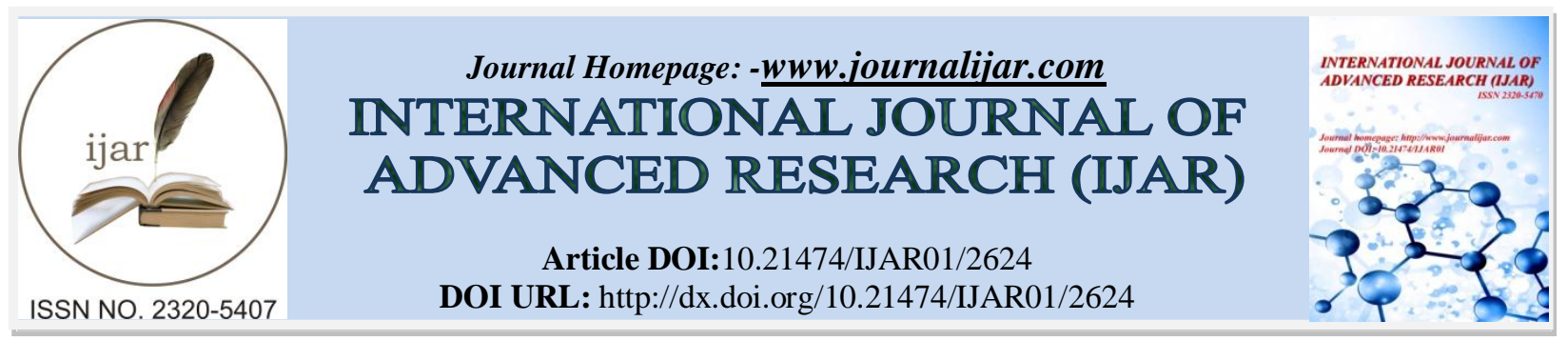

RESEARCH ARTICLE

\title{
MISUSE OF ANTIBIOTICS IN PEDIATRIC GASTROENTERITIS OF AL-SADDER TEACHING HOSPITAL IN MISAN PROVINCE, IRAQ.
}

"Dr. Esraa Abd Al-Muhsen Ali.

M.B. Ch.B , C.A.B.P, D.C.H., Pediatrics Department, College of Medicine, Misan University, Misan, Iraq.

\section{Manuscript Info}

Manuscript History

Received: 30 October 2016

Final Accepted: 29 November 2016

Published: December 2016

Key words:-

Antibiotics, misuse, overuse,

gastroenteritis, diarrhea.

\section{Abstract}

Background:Antibiotics are the most commonly prescribed drugs in many developed and developing countries. Overuse of antibiotics result not only in the emergence of resistant bacteria but also in adverse reactions and economic burden on health system.

Aim of study: To estimate the extent of antibiotics' misuse in children less than 5 years with gastroenteritis.

Patients and methods: A cross-sectional study was carried out in AlSadder Teaching Hospital in Misan Province, South East of Iraq, during period from $15^{\text {th }}$ November 2015 to $15^{\text {th }}$ February 2016.

Three hundred patients with gastroenteritis had been admitted to Pediatric Ward were enrolled in the study. Data were collected from patients' files.

Results:290 (96.67\%) cases were received antibiotics while 10 (3.33\%) cases were not. Majority of cases of $(74.83 \%)$ received two antibiotics. And the most common antibiotics were third generation cephalosporin followed by metronidazole.

Conclusion: Obviously there was a definite misuse of antibiotics in children under five years during an episode of diarrhea. Adherence to recommended guidelines in gastroenteritis treatment will limit this problem.

Copy Right, IJAR, 2016,. All rights reserved.

\section{Introduction:-}

Acute gastroenteritis (GE) in children is often defined as the onset of diarrhea in the absence of chronic disease, with or without abdominal pain, fever, nausea, or vomiting(1).Diarrhoea is the passage of excessively liquid or frequent stools with increased water content. Patterns of stooling vary widely in young children, and diarrhoea represents a change from the norm(2).It is a major cause of pediatric morbidity and mortality around the world, accounting for 35 billion cases of acute GE and nearly 2 million deaths occur each year in children under 5 years $(3,4)$. Children in the United States experience, on average, 1.3-2.3 episodes of diarrhea each year. Overall, acute GE accounts for more than 1.5 million outpatient visits, 220,000 hospitalizations, and direct costs of more than $\$ 2$ billion each year in the United States alone(5).Viruses remain by far the most common cause of acute GE in children, both in industrialized countries and developing nations(6), with Rotaviruses andNoroviruses being most common(7).Generally, the management of GE aims to prevent and treat dehydration, maintain nutrition, and minimize harm $(8,9)$. Over the last 30 years the incidence of diarrhea-related mortality has dramatically decreased. Following introduction of oral rehydration salts (ORS) and educational programs largely spearheaded by the World Health Organization (WHO), diarrhea-related annual mortality dropped from 13.6 to 4.9 deaths per 1000 children 
under five. Evidence has shown large-scale diarrhoea and dehydration treatment programs to be effective worldwide(10).

Antibiotics are not indicated in viral or uncomplicated bacterial GE and may cause harm. For example, in nontyphoid Salmonella infections antibiotics increase the risk of prolonged carriage and disease relapse. Treating GE due to Shiga toxin producing E coli with antibiotics may increase the risk of haemolyticuraemic syndrome. Antibiotics are required, however, for bacterial GE complicated by septicaemia and in cholera, bloody diarrhoea, giardiasis, serious non-intestinal infections such as pneumonia, eradication of fecal shedding and transmission, and prevention of sequellae and death $(8,9,11)$. Antibiotic misuse, sometimes called antibiotic abuse or antibiotic overuse, refers to the misuse or overuse of antibiotics, with potentially serious effects on health. It is a contributing factor to the development of antibiotic resistance, including the creation of multidrug-resistant bacteria, informally called "super bugs": relatively harmless bacteria can develop resistance to multiple antibiotics and cause lifethreatening infections(12). Antibiotics are the most commonly prescribed drugs in many developed (13) and developing countries(14). WHO estimated that $80 \%$ of antibiotics are used in the community, of which about $20-$ $50 \%$ is used inappropriately (15). Excessive antibiotic consumption is increasingly recognized as the main or rather the only cause of the emerging antibiotic resistance (16).

The International network of surveillance system monitoring data on antibiotic use in Europe through the ESAC project (European Surveillance of Antibiotic Consumption); found that the highest rates of antibiotic resistance were seen in countries with the highest consumption rate of antibiotics(17).

The irrational and overuse of antibiotics result not only in the emergence of resistant bacterial strains but also in adverse reactions and economic burden on national health system(18).According to this context, there should be a wise use of available antibiotics(19).

\section{Patients and methods:-}

A cross-sectional (descriptive)study was carried out in Al-Sadder Teaching Hospital in Misan Province, South East of Iraq, during period from $15^{\text {th }}$ November 2015 to $15^{\text {th }}$ February 2016

Three hundred patients with GE had been admitted to the Pediatric Ward were enrolled in the study.

A physician collected data from patients' files. Routinely, in the Al-Sadder Teaching Hospital, data on demographic characteristics of the subjects were gathered on the patients' arrival. The data was collected using special formula constructed by the researcher and based on the standard criteria including: name, age (date of birth), gender, date of admission, use of antibiotics or not, and type with number of used antibiotics.

Exclusion criteria; marasmus, kwashiorkor, chronic illness, severely ill patients, and those patients who do not meet the study criteria.

The study protocol was reviewed; approval and official permission were obtained from the Ministry of Higher Education, Misan directorate of health and Al-Sadder Teaching Hospital to conduct the present study. The analysis of data was carried out using the available Statistical Packages for Social Science, version 16.0 (SPSS-16.0). Data were presented in form of table of number and percentage.

\section{Results:-}

A total of 300 cases of GE were divided into 2 groups according to gender: 165 (55\%) were male while 135 (45\%) were female patients as shown in table 1 .

Table 1: Gender classification of pediatric gastroenteritis.

\begin{tabular}{|l|l|l|}
\hline Gender & Number & Percentage \\
\hline Male & 165 & $55 \%$ \\
\hline Female & 135 & $45 \%$ \\
\hline Total & 300 & $100 \%$ \\
\hline
\end{tabular}

The cases were classified into 2 groups according to antibiotics' prescription; 290 (96.67\%) cases were received antibiotics while $10(3.33 \%)$ cases were not treated with antibiotics as shown in table 2. 
Table 2: Number \& percentage of patients with antibiotics \& without antibiotics use.

\begin{tabular}{|l|l|l|}
\hline $\begin{array}{l}\text { Number of cases } \\
\text { No. }(\%)\end{array}$ & $\begin{array}{l}\text { Use antibiotics } \\
\text { No. (\%) }\end{array}$ & $\begin{array}{l}\text { Not use antibiotics } \\
\text { No. (\%) }\end{array}$ \\
\hline 300 & $290(96.67 \%)$ & $10(3.33 \%)$ \\
\hline
\end{tabular}

The total cases of 290 that used antibiotics were classified according to the number of antibiotics; in which there were $40(13.79 \%)$ cases received one antibiotic while $217(74.83 \%)$ and 33(11.38\%) were received two and three antibiotics respectively as shown in table 3.

Table 3: Number \& percentage of patients according to the number of antibiotics use.

\begin{tabular}{|l|l|l|}
\hline Antibiotics use & Number & Percentage \\
\hline One antibiotic & 40 & $13.79 \%$ \\
\hline Two antibiotics & 217 & $74.83 \%$ \\
\hline Three antibiotics & 33 & $11.38 \%$ \\
\hline Total & 290 & $100 \%$ \\
\hline
\end{tabular}

Third generation cephalosporin was on the top of antibiotics' list that used to treat GE; it was used in254 (87.59\%) cases. The second drug was metronidazole which was given in $252(86.89 \%)$ casewhile aminoglycoside and penicillin were prescribed in 43(14.83\%) \&24(8.27\%) cases respectively asshown in table 4.

Table 4:- Number \& percentage of patients according to the type of antibiotics use.

\begin{tabular}{|l|l|l|}
\hline Type of antibiotics & Number & Percentage \\
\hline $\mathbf{3}^{\text {rd }}$ generation cephalosporin & 254 & $87.59 \%$ \\
\hline Metronidazole & 252 & $86.89 \%$ \\
\hline Aminoglycoside & 43 & $14.83 \%$ \\
\hline Penicillin & 24 & $8.27 \%$ \\
\hline
\end{tabular}

\section{Discussion:-}

Antibiotics are the key drugs for treatment of infections and are among the most commonly prescribed drugs in pediatrics department (20). However, the misuse of antibiotics in children has been well documented and has many serious health effects (21).

The current study showed that the majority of children less than 5 years who had admission in Pediatric Ward of AlSadder Teaching Hospital in Misan Province were treated with antibiotics; there was obvious misuse of antibiotics in pediatric GE.

A 290 (96.67\%) of pediatric GE had been treated with antibiotics during hospitalization which was much higher than that found in Saudi Arabia, 2011 which showed that less than half (43.2\%) of the cases presented with acute GE were prescribed antibiotics(22).On the other hand, it was also higher than that seen in India, 2012 in which less than three fourth $(72.26 \%)$ of the cases presented with acute GE were received antibiotics(23).

This problem is also found in nearby countries like; Jordan(24),Saudi Arabia(25), and other countries like Nigeria(26) and it iscurrently considered to be one of the major public health issues.

Most cases in this study were treated with two antibiotics which were forming 217 (74.83\%).

Third generation cephalosporin with metronidazole were forming the most prescribed antibiotics in pediatric GE in which there were $254(87.59 \%)$ and $252(86.89 \%)$ cases respectively.

Astudy in Saudi Arabia (Jazan region) in 2014 revealed that GE was the third cause for prescription of antibiotics (after fever and pneumonia) and the most frequently prescribed antibiotics were cephalosporin group (52\%) followed by aminoglycoside group (17.3\%), penicillin (12.5\%), macrolides $(8.3 \%)$ and quinolones $(0.69 \%)(25)$.

Obviously thepercentage for cephalosporin in Misan study was higher than that of Saudi Arabia while the opposite for aminoglycoside group and penicillin which is less than Saudi Arabia. 
Another study conducted in Baghdad (capital city of Iraq), 2012 on outpatient GE revealed that Trimethoprimsulfamethoxazole (TMP-SMX) was the most antimicrobial used in $39.75 \%$ followed by Metronidazole suspension $35.5 \%$ and gentamycin injection in $17.5 \%$ of the total(27).

When do comparison; the cephalosporin group was the first antibiotic used in the present study while TMP-SMX was the first in Baghdad study; this may be explained by the differences in choosing GE cases from inpatient or outpatient department.On the other hand, the percentage of metronidazole was higher than Baghdad while the percentage ofaminoglycoside was less.

However, antimicrobial agents do not benefit most children with acute diarrhea because viral enteropathogens are so common $(7,9)$. So the routine use of antibiotics in pediatric GE should be prohibited with more attention to follow indicationand policy of antibiotics use in GE cases.Furthermore, there is empirical evidence that adherence to recommended care for children with acute GE decreases costs, length of hospital stay, and duration of illness (28, 29).

\section{Conclusion:-}

Misuse of antibiotics in pediatric gastroenteritis was obvious in Pediatric Ward of Al-Sadder Teaching Hospital in Misan Province. Restriction to the guidelines in treating pediatric gastroenteritis cases would decrease the misuse of antibiotics.

\section{Acknowledgment:-}

I would like to thank all the persons that they have great efforts to complete this work especiallyDr.HmoudMadhi Hassan (FICMS/ CM) and Dr.ZainabDia Al-Deen (M.B. Ch.B).

\section{Interest of conflict:}

There is no interest of conflict with any organization and this research is not funded.

\section{References:-}

1. Churgay C. (2012). Gastroenteritis in Children: Part I. Diagnosis. Am Fam Physician. 85(11): $1059-62$.

2. Tham EB, Nathan R, Davidson GP, Moore DJ. (1996). Bowel habits of healthy Australian children aged 0-2 years. J Paediatr Child Health. 32: 504-7.

3. Black RE, Cousens S, Johnson HL, Lawn JE, Rudan I, Bassani DG, et al. (2010). Global, regional, and national causes of child mortality in 2008: a systematic analysis. Lancet.375(9730): 1969-87.

4. Bryce J, Boschi-Pinto C, Shibuya K, Black RE; WHO Child Health Epidemiology Reference Group.(2005). WHO estimates of the causes of death in children.Lancet.365: 1147-52.

5. Dennehy PH. (2005). Acute diarrheal disease in children: epidemiology, prevention, and treatment. Infect Dis Clin North Am. 19(3): 585-602.

6. kosek M, gurrant RL. (2003). The global burden of diarrheal disease as estimated from studies published between 1992 and 2000. Bull world health organ. 81(3):197-204.

7. Kirkwood CD, Bogdanovic-Sakran N, Cannan D, Bishop RF, Barnes GL. (2006).National rotavirus surveillance program annual report 2004-5.Commun Dis Intell .30:133-6.

8. World Health Organization. (2005). The treatment of diarrhoea - a manual for physicians and other senior health workers. 4th rev. Geneva: WHO, 2005.

9. Elliott E J. (2007).Acute gastroenteritis in children.BMJ. 334: 35-40.

10. Boschi-Pinto C, Vilibet L, Shibuy K. (2008).Estimating child mortality due to diarrhoea in developing countries. Bull world health organ.86 (9): 710-7.

11. Pickering LK.(2004). Antimicrobial resistance among enteric pathogens.SeminPediatr Infect Dis. 15: $71-77$.

12. Harrison JW, Svec TA.(1998). "The beginning of the end of the antibiotic era? Part II. Proposed solutions to antibiotic abuse".Quintessence International.29 (4): 223-9.

13. Van Bijnen EM, den Heijer CD, Paget WJ, Stobberingh EE, Verheij RA, Bruggeman CA, et al. (2011). The appropriateness of prescribing antibiotics in the community in Europe: study design. BMC infectious diseases.11: 293.

14. Ahiabu MA, Tersbol BP, Biritwum R, Bygbjerg IC, Magnussen P. (2015).A retrospective audit of antibiotic prescriptions in primary health-care facilities in Eastern Region, Ghana.Health policy and planning.Epub 2015/06/06. 
15. WHO. The world health report 2007. A safer future: global public health security in the 21 st century. World Health Organization.

16. Bronzwaer SL, Cars O, Buchholz U, Mölstad S, Goettsch W, Veldhuijzen IK, et al. (2002). European Antimicrobial Resistance Surveillance System A European study on the relationship between antimicrobial use and antimicrobial resistance. Emerg Infect Dis. 8(3): 278-82.

17. Goossens H, Ferech M, Vander Stichele R, Elseviers M, ESAC Project Group. (2005). Outpatient antibiotic use in Europe and association with resistance: a cross-national database study. Lancet. 365(9459): 579-87.

18. Gyssens I.C. (2001). Quality measures of antimicrobial drug use. Int. J. Antimicrob. Agents. 17:9-19.

19. Newland JG, Hersh AL. (2010).Purpose and design of antimicrobial stewardship programs in pediatrics.Pediatr Infect Dis J. 29: 862-63.

20. Choudhury DK, Bezbaruah BK. (2013). Antibiotic Prescriptions Pattern in Paediatric in-Patient Department Gauhati Medical College and Hospital, Guwahati. J App Pharm Sci. 3(08): 144-48.

21. Zwar N, Henderson J, Britt H, McGeechan K, Yeo G. (2002).Influencing antibiotic prescribing by prescriber feedback and management guidelines: a 5-year follow-up.FamPract. 19:12-17.

22. Zolaly M.A, Hanafi M.I. (2011).Factors Affecting Antibiotics' Prescription in General Pediatric Clinics.Journal of Taibah University Medical Sciences.6 (1): 33-41.

23. Pallavi N, Totade S, Chetna G, Patel JR. (2012).An Assessment of Factors Affecting Antibiotic Prescription in Pediatric Department of Rural Tertiary Care Teaching Hospital, Wardha District, Maharashtra.RJPBCS.3(3): 921-28.

24. Al-Armouti M, Khashman M, Al-Refa'ai R. (2015). Evaluation of Antibiotic's Use Among Children During Hospitalization. European Scientific Journal.11(18): 253-58.

25. Alakhali KM, Ansari AS. (2014). Prescribing Pattern of Antibiotics in Pediatric Patients in the Jazan Region, Kingdom of Saudi Arabia. RGUHS J Pharm Sci. 4(3): 120-24.

26. Ekwochi U, Chinawa JM, Obi I, Obu HA, Agwu S. (2013).Use and/or Misuse of Antibiotics in Management of Diarrhea Among Children in Enugu, Southeast Nigeria.J Trop Pediatr.59(4):314-6.

27. Lafta RK, Al-shatari SA, Hassan RA. (2014). Drug Misuse in the Treatment of Diarrhea Among Children Under Five Years; a Sample from Baghdad. Iraqi J. Comm. Med. 1: 14-17.

28. Tieder JS, Robertson A, Garrison MM. (2009).Pediatric hospital adherence to the standard of care for acute gastroenteritis.Pediatrics.124(6): 1081-87.

29. Perlstein PH, Lichtenstein P, Cohen MB, Ruddy R, Schoettker PJ, Atherton HD, et al. (2002).Implementing an evidence-based acute gastroenteritis guideline at a children's hospital.JtComm J QualImprov. 28(1): 20-30. 